\title{
Evaluation of different drinking water sources in Sokoto North-West Nigeria on performance, carcass traits and haematology of broiler chickens
}

\author{
E. B. Ibitoye ${ }^{1}$, Y. U. Dabai ${ }^{2}$ and L. Mudi ${ }^{1}$
}

1. Department of Theriogenology and Animal Production, Faculty of Veterinary Medicine, Usmanu Danfodiyo University Sokoto, Nigeria; 2. Department of Veterinary Microbiology, Faculty of Veterinary Medicine, Usmanu Danfodiyo University Sokoto, Nigeria

Corresponding author: E.B. I bitoye, email: emmavet2001@hotmail.com; Tel: +2347038228200

Received: 28-07-2013, Revised: 01-09-2013, Accepted: 03-09-2013, Published online: 08-10-2013

doi: $10.14202 /$ vetworld.2013. 879-883

How to cite this article: I bitoye EB, Dabai YU and Mudi L (2013) Evaluation of different drinking water sources in Sokoto North-West Nigeria on performance, carcass traits and haematology of broiler chickens, Veterinary World 6(11): 879-883.

\begin{abstract}
Aim: The study examined the effect of different drinking water sources on performance, carcass characteristics and haematology of broiler chickens.

Materials and Methods: 63 unsexed day-old broiler chicks were randomly grouped into three treatment groups (Treatments 1,2 and 3), each consisting of three replicates of seven chicks each. Treatments 1, 2 and 3 were given water from various sources: pipe borne water; borehole water and well water, respectively from day-old to seven weeks of age. The water samples were subjected to physico-chemical and bacteriological analyses.

Results: Physico-chemically, only well water had a fair taste, it also had highest turbidity; while borehole water was least turbid. Borehole water had highest total hardness, nitrate, sodium, and calcium. Chloride was higher in borehole water and magnesium was higher in well water; while these were absent in pipe borne water. The study revealed that all water sources were contaminated with bacteria. The well water had the highest bacterial load of $1.2 \times 10^{3} \mathrm{cfu} / \mathrm{ml}$, followed by borehole water with $5.8 \times 10^{2} \mathrm{cfu} / \mathrm{ml}$, while pipe borne water recorded least bacterial counts $\left(1.6 \times 10^{2} \mathrm{cfu} / \mathrm{ml}\right)$. Escherichia coli, Klesiella spp and Proteus vulgaris were isolated from pipe borne, borehole and well water, respectively. The water treatments had no significant ( $p>0.05)$ effect on broiler chicken's performance, carcass characteristics and haematological indices. However, numerical increase in feed intake and weight gain was observed in birds placed on borehole water (Treatment2).
\end{abstract}

Conclusion: This study suggest that different water sources used as drinking water in this experiment have no significant effect on performance, carcass characteristics and haematology of broiler chicken production in Sokoto metropolis. However, drinking water quality standard for poultry should not be jeopardized.

Keywords: bacteriological analysis, broilers, carcass characteristics, haematology, performance, water

\section{Introduction}

Water is the single most critical nutrient to health and well being [1]. It is a necessary agent in all body processes and is the most critical nutrient for the production of poultry [2]; this explains the relevance of water in the well being and performance of poultry chickens. Good quality water is essential for the production of livestock and poultry, it is an essential ingredient for life, nutrient and is also involved in many essential physiological functions such as, digestion, absorption, enzymatic function, nutrient transportation, thermoregulation, lubrication of joints and organs, elimination of waste [3]. It is also an essential component of blood and tissues [3].

Achicken's body weight is $70 \%$ water and $85 \%$ of chicks'; a loss of only $10 \%$ of that water will result in

Copyright: The authors. This article is an open access article licensed under the terms of the Creative Commons Attribution License (http://creativecommons.org/licenses/by/2.0) which permits unrestricted use, distribution and reproduction in any medium, provided the work is properly cited. the bird's death [4]. According to Abdullah [3], chicken can survive for longer periods without any other nutrient than they can survive without water. Limitations on water intake depress animal performance quickly and more drastically than any other nutrient deficiency [5]. High ambient tempera-ture can have heavy impact on birds' water intake. Under normal conditions, the water intake of chickens approximately doubles that of feed intake (1.8:1). However, during hot weather water intake will be increased up to 3 times that of feed intake [6]. Broiler drinks a great deal of water; during its life time, a $2.3 \mathrm{~kg}$ broiler will consumes about $8.2 \mathrm{~g}$ of water compared to approximately $4.6 \mathrm{~kg}$ of feed [7]. In view of these functions and importance of water, it is therefore necessary that for efficient growth and production performance, animals should be provided with adequate clean water at all times. Although animal can derive their water from feed and through the body metabolic processes, drinking water still accounts for $70 \%$ of the sources of water to the animals $[8,9]$. 
Poultry production has gained attention in Sokoto in recent years. The amount of water supply to the animal is often influenced by the quantity available and the judgment of the attendants which often results in under supply of water. Most poultry farmers live in peri-urban areas and villages which lack portable water for both human and livestock consumption. Furthermore, in certain areas of the tropics like Sokoto in northern Nigeria, which is characterized by long and severe dry season, water is not available all the year round [10].

There is paucity of information on the effect of different water sources on broiler production. Consequently, this study tends to evaluate the effects of different water sources on broiler production, with particular attention to performance, carcass characteristics and haematology.

\section{Materials and Methods}

Ethical approval: Authors followed all the national legislation concerning protection of animal welfare and following the guidelines of the Ethics Committee.

Study area: This study was carried out in Sokoto, Sokoto State Nigeria. The state is located in the NorthWestern Zone of Nigeria and lies between $13^{\circ} 04^{\prime} \mathrm{N}$ and $05^{\circ} 14^{\prime} \mathrm{E}$ [11]. It is 308 meter above sea level. It has a land area of approximately 56,000 square kilometers. It is bordered in the North by Niger Republic, Zamfara State to the East and Kebbi State to the South and West [12]. There are two major seasons in Sokoto namely wet and dry. The dry season starts from October, and lasts up to April in some parts and it may extend to May or June in other Parts. The wet season on the other hand begins in most parts of the state in May and lasts up to September, or October. The harmattan, a dry, cold and fairly dusty wind is experienced in the state between November and February. Heat is more severe in the state in March and April. Rainfall starts late and ends early with mean annual falls ranging between $500 \mathrm{~mm}$ to $1,300 \mathrm{~mm}$ [11].

Experimental site: The research was carried out at the Poultry unit of the Department of Theriogenology and Animal Production, Faculty of Veterinary Medicine, Usmanu Danfodiyo University Sokoto, Nigeria.

Waters sources and their analyses: Three different sources of water were used for this study: pipe borne water (PPW) obtained from a tap within the campus complex of the Faculty of Veterinary Medicine, Usmanu Danfodiyo University Sokoto, Nigeria. The borehole water (BW) was obtained from the borehole that supplies water to the reservoir, also within the campus, and the well water (WW) was obtained from a residential building well very close to the campus. The water samples were obtained in separate clean 25 litres containers and each were kept for less than three days.

The water samples were collected using sterilized glassware containers and were transported to the laboratory of Sokoto State Water board for physicochemical analysis, by a method described by Snell
[13]. Physico-chemical analysis of waters was carried out to determine colour, odour, taste, $\mathrm{pH}$, temperature, turbidity, conductivity, total hardness, total dissolved solids, iron, nitrate, sulphate, phosphate, sodium, calcium, magnesium and chloride. Another part of the water samples were also transported in cool boxes to the Veterinary microbiology/pathology laboratory of the Faculty of Veterinary Medicine, Usmanu Danfodiyo University Sokoto, Nigeria for immediate bacteriological analysis. The bacteriological isolation and identification from the water samples was analysed according to the procedure described by Cheesbrough [14], and a method outlined by Fawole and Oso [15] was used for bacterial count.

Management of experimental birds: 63 unsexed dayold broiler chicks were used in this study.The chicks were randomly allotted three treatments of twenty-one birds in each treatment (treatments 1, 2 and 3). The treatments 1,2, and 3 were given pipe borne, borehole and well water, respectively. Also, each treatment was replicated thrice with seven birds per replicate. The chicks were brooded and raised on deep litter system. The birds were given commercially prepared feed $a d$ libitum; they were given broiler starter from day old to 4 week of age and broiler finisher from 5-7 weeks of age. Routine vaccinations and medications were administered during seven weeks trial.

Data collection: The experiment lasted for seven weeks during which mean weekly weight, mean weekly weight gain, and mean weekly feed consumed were recorded. The feed conversion ratio was determined using the formula: Feed conversion ratio $=$ Total feed intake $(\mathrm{kg} / \mathrm{bird}) \div$ Body weight gain $(\mathrm{kg} / \mathrm{bird})$.

Blood collection and carcass characteristics: At the end of the feeding trial, birds were starved overnight to stabilize them, after which two birds were randomly sampled from each replicate. They were weighed and sacrificed using Halaal/Koscher method. For haematology, blood samples were collected into labeled sterilized bottles containing dry Ethylene DiamineTetra-acetic Acid (EDTA). The packed cell volume (PCV), red blood cell (RBC), white blood cell (WBC) and its differentials were determined by haematocrit and haemocytometer method. The carcasses were defeathered, washed and eviscerated. The carcasses were then cut into different parts and weighed using the sensitive electronic Mettler balance PM16-K model.

Statistical analysis: Data collected on performance, carcass characteristics and haematology were subjected to one way analysis of variance (ANOVA) and significant means were compared with post hoc test, using GraphPad Instat package 3.06 version. Ther results were considered significant at $\mathrm{p}<0.05$. All data were presented in tables as mean $\underline{ \pm}$ standard error mean.

\section{Results}

Water analyses: The physico-chemical analyses of 
Table-1. Physico-chemical analysis of sampled water

\begin{tabular}{llll}
\hline Parameters & \multicolumn{3}{c}{ Water sources } \\
\cline { 2 - 4 } & PPW & BW & WW \\
\hline Colour & Colourless & Colourless & Colourless \\
Odour & Inoffensive & Inoffensive & Inoffensive \\
Taste & Tasteless & Tasteless & Fair \\
pH & 6.3 & 6.1 & 6.4 \\
Turbidity & 10.4 & 8.8 & 14.9 \\
Conductivity & 30.1 & 30.2 & 30.2 \\
Total hardness (mg/l) & Nil & 18.5 & 15.0 \\
Total dissolved solid (ppt) & 0.2 & 0.2 & 0.6 \\
Iron (mg/l) & 0.2 & 1.4 & 1.4 \\
Nitrate (mg/l) & 1.7 & 3.2 & 3.1 \\
Sulphate (mg/l) & 4.2 & 3.8 & 4.0 \\
Phosphate (mg/l) & 4.1 & 4.0 & 4.5 \\
Sodium (mg/l) & 1.2 & 3.0 & 2.8 \\
Calcium (mg/l) & 0.0 & 9.5 & 8.0 \\
Magnesium (mg/l) & 0.0 & 7.0 & 9.0 \\
Chloride (mg/l) & 0.8 & 1.6 & 1.1 \\
\hline
\end{tabular}

PPW = Pipe borne water, BW = Borehole water, $\mathrm{WW}=$ Well water

Table-2. Bacterial analysis of experimental waters

\begin{tabular}{lcl}
\hline Water samples & Bacterial load $(\mathbf{c f u} / \mathbf{m l})$ & Bacterial isolates \\
\hline PPW & $1.6 \times 10^{2}$ & Escherichia coli \\
BW & $5.8 \times 10^{2}$ & Klesiella spp \\
WW & $1.2 \times 10^{3}$ & Proteus vulgaris \\
\hline
\end{tabular}

$\mathrm{PPW}=$ Pipe borne water, $\mathrm{BW}=$ Borehole water, $\mathrm{WW}=$ Well water

Table-3. Performance of broiler chickens given different sources of water

\begin{tabular}{lllll}
\hline Performance parameters & \multicolumn{3}{c}{ Water sources } & \multirow{2}{*}{ SEM } \\
\cline { 2 - 4 } & PPW & BW & WW & \\
\hline Initial body weight $(\mathrm{kg} / \mathrm{bird})$ & $0.05 \pm 0.005$ & $0.05 \pm 0.005$ & $0.05 \pm 0.005$ & 0.005 \\
Final body weight $(\mathrm{kg} / \mathrm{bird})$ & $1.64 \pm 0.106$ & $1.83 \pm 0.106$ & $1.48 \pm 0.106$ & 0.106 \\
Body weight gain $(\mathrm{kg} / \mathrm{bird})$ & $1.60 \pm 0.101$ & $1.78 \pm 0.101$ & $1.43 \pm 0.101$ & 0.101 \\
Total feed intake $(\mathrm{kg} / \mathrm{bird})$ & $5.08_{ \pm 0.33}$ & $5.62 \pm 0.33$ & $4.47 \pm 0.33$ & 0.33 \\
Feed conversion ratio & $3.19_{ \pm 0.017}$ & $3.16 \pm 0.017$ & $3.13 \pm 0.017$ & 0.017 \\
\hline
\end{tabular}

$\mathrm{PPW}=$ Pipe borne water, $\mathrm{BW}=$ Borehole water, $\mathrm{WW}=$ Well water, $\mathrm{SEM}=$ Standard Error Mean

Table-4. Carcass characteristics of broiler chickens given different sources of water

\begin{tabular}{|c|c|c|c|c|}
\hline \multirow[t]{2}{*}{ Performance parameters } & \multicolumn{3}{|c|}{ Water sources } & \multirow[t]{2}{*}{ SEM } \\
\hline & PPW & BW & WW & \\
\hline Live weight (kg/bird) & $1.64 \pm 0.106$ & $1.83 \pm 0.106$ & $1.48 \pm 0.106$ & 0.106 \\
\hline Dressed weight (kg/bird) & $1.60 \pm 0.11$ & $1.80 \pm 0.11$ & $1.39 \pm 0.11$ & 0.11 \\
\hline \multicolumn{5}{|c|}{ Average carcass weight as $\%$ of live weight } \\
\hline Legs & $20.40 \pm 1.66$ & $21.88 \pm 1.66$ & $20.75 \pm 1.66$ & 1.66 \\
\hline Wings & $7.00+0.46$ & $8.60+0.46$ & $7.00+0.46$ & 0.46 \\
\hline Neck & $3.50+0.20$ & $4.08+0.20$ & $4.28+0.20$ & 0.20 \\
\hline Back & $18.18 \pm 0.14$ & $17.7 \overline{5} \pm 0.14$ & $17.6 \overline{5} \pm 0.14$ & 0.14 \\
\hline Breast & $17.83 \pm 2.73$ & $20.58 \pm 2.73$ & $19.35 \pm 2.73$ & 2.73 \\
\hline
\end{tabular}

PPW = Pipe borne water, $\mathrm{BW}=$ Borehole water, $\mathrm{WW}=$ Well water, $\mathrm{SEM}=$ Standard Error Mean

sampled water are presented in Table-1.It showed that WW had a fair taste compared to other sources of water. Turbidity was highest in WW, followed by PPW, while $\mathrm{BW}$ was least turbid. Borehole water had highest total hardness, while there was no trace in PPW. Nitrate, sodium, calcium and chloride were higher in BW, magnesium is higher in WW, while they were absent in PPW. In Table- 2 , WW had the highest bacterial load of $1.2 \times 10^{3} \mathrm{cfu} / \mathrm{ml}$, followed by BW $\left(5.8 \times 10^{2} \mathrm{cfu} / \mathrm{ml}\right)$ then PPW $\left(1.6 \times 10^{2} \mathrm{cfu} / \mathrm{ml}\right)$. Escherichia coli, Klesiella $\mathrm{spp}$ and Proteus vulgaris were isolated from PPW, BW and WW, respectively.

Performance, carcass and haematological records: The performance of broiler chickens provided water from different sources is shown in Table-3. The result indicates that the different water sources had no significant $(\mathrm{P}>0.05)$ effect on all the performance indices measured. Birds placed on BW had the highest numerical value for most of the performance parameters measured, such as total feed intake (5.62 \pm $0.33 \mathrm{~kg} / \mathrm{bird})$, body weight gain $(1.78 \pm 0.10 \mathrm{~kg} / \mathrm{bird})$ and final body weight $(1.83 \pm 0.11 \mathrm{~kg} / \mathrm{bird})$.

The results of carcass traits and haematological indices of broiler chickens reared on water from different sources are presented in Tables-4 and 5, respectively. Data in Table-4 showed that the treatments had no significant $(\mathrm{P}>0.05)$ effect on the eviscerated weight and carcass parts (legs, wings, neck, 
Table-5. Haematological variables of broiler chickens given different sources of water

\begin{tabular}{lllll}
\hline Performance parameters & \multicolumn{3}{c}{ Water sources } & \multirow{2}{*}{ SEM } \\
\cline { 2 - 4 } & PPW & B W & WW & \\
\hline PCV $(\%)$ & $25.0 \pm 1.99$ & $30.5 \pm 1.99$ & $31.5 \pm 1.99$ & 1.99 \\
RBC $\left(\times 10^{6} / \mathrm{mm}^{3}\right)$ & 2.59 & 2.59 & 2.59 & 0.00 \\
WBC $\left(\times 10^{6} / \mathrm{mm}^{3}\right)$ & $12.05 \pm 0.86^{\mathrm{a}}$ & $9.79 \pm 0.86^{\mathrm{a}, \mathrm{b}}$ & $9.23 \pm 0.86^{\mathrm{b}}$ & 0.86 \\
Heterophils $(\%)$ & $26.0 \pm 4.06$ & $24.0 \pm 4.06$ & $27.5 \pm 4.06$ & 4.06 \\
Lymphocytes $(\%)$ & $66.8 \pm 1.96$ & $72.5 \pm 1.96$ & $66.5 \pm 1.96$ & 1.96 \\
Monocytes $(\%)$ & $6.3 \pm 0.51$ & $5.3 \pm 0.51$ & $4.5 \pm 0.51$ & 0.51 \\
Eosinophils $(\%)$ & $1.0 \pm 0.22$ & $0.8 \pm 0.22$ & $1.5 \pm 0.22$ & 0.22 \\
Basophils $(\%)$ & 0.0 & 0.0 & 0.0 & 0.0 \\
\hline
\end{tabular}

PPW = Pipe borne water, BW = Borehole water, WW = Well water, SEM = Standard Error Mean, Mean value along the same row with different superscripts are significantly different $(P<0.05)$

However, birds placed on BW had the highest numerical values for the dressed weight $(1.80 \pm 0.11$ $\mathrm{kg} / \mathrm{bird})$, legs $(21.88 \pm 1.66 \%$ of live weight $)$, wings $(8.60 \pm 0.46 \%$ of live weight $)$ and breast $(20.58 \pm 2.73$ $\%$ of live weight), while birds that drank WW had the least values for carcass traits. Similarly, the haematological indices were not significantly influenced by water from different sources, except for WBC, which is significantly $(\mathrm{P}<0.05)$ highest in birds on PPW $(12.05$ $\times 10^{3} / \mathrm{mm}^{3}$ ).

\section{Discussion}

The presence of queried physico-chemical elements in all the water samples sources evaluated suggest drinking water cannot be totally free of these elements. This agrees with the report of Asaniyan et al. [16]. The highest turbidity in WW of this study is in agreement with the findings of Abbas et al. [17]. This might be due to frequent stirring by fetchers and contaminant. The highest hardness level in this study was obtained from BW. This contradicts the report of Abbas et al. [17], who reported highest total hardness in WW. This might be due to differences in geographic locations; it could also be as a result of high level of soil mineral content, especially calcium and magnesium in the water. The highest level of nitrate observed in BW and its presence established in PPW contradict the findings of Abbas et al. [17], who reported highest nitrate in WW and absence in PPW. This might be due to the differences in geographical regions. The highest concentration of sodium in borehole water agrees with the reports by Asaniyan et al. [16] and Folorunsho et al . [18].

The highest bacterial count observed in WW coincides with the report from Asaniyan et al. [16] and Abbas et al. [17], probably due to vulnerability to various pollutants and contamination by people fetching water from it. The presence of bacteria in PPW contradicts reports of Asaniyan et al. [16] and Abbas et al. [17]. This might be due to poor sanitary conditions around the taps and pipes that convey the water from source.

The results of this study showed that water from different sources had no significant effect on performance indices of broiler chickens. The result is consistent with the several previous reports [19-21]. This implies that water from PPW, BW and WW will be tolerated by broiler chickens, as long as such water is devoid of any contaminants that could adversely affect the health of the birds.

The overall carcass growth showed that the different water sources had no significant effect on the carcass characteristics. This agrees with the findings of Asaniyan et al. [16] and Folorunsho et al. [20], who reported similar findings, it may be due to insignificant effect on feed intake and feed conversion ratio.

Similarly, different water sources had no significant effect on majority of haematological parameters of birds under this study except for WBC. This implies that different sources of water used in this study had no adverse effect on the haematology of broiler chickens. This study had results similar to the study conducted by Asaniyan and Adene [21] in the south-west Nigeria. The white blood cell count of all the treatments significantly fell below the mean value of 16.65 units reported by Chauhan and Roy [22]. This might be due to the chronic exposure of all experi-mental birds to various kinds of bacteria, as WBC is responsible for defense mechanism of the body.

\section{Conclusion}

The results revealed that broiler chickens placed on different water sources had significantly similar performance, carcass characteristics and haematological values. Similarly, impact of total bacterial counts and the identified organisms were not significantly different. Therefore, from this study, any of the studied water sources could be used in broiler production without any detrimental effects. However, drinking water quality standard for poultry should not be overlooked.

However, Agriculture and Agric-food Canada [23] reported that though bird's health might not be affected by water contaminations, their potential impact on product quality should be considered, as some compound may get deposited in eggs, meat, bone and/or liver. Therefore, similar investigation should be conducted to evaluate the effect of these water sources on these organ weights. Further studies should be performed using layers as they are being raised for longer period of time. Additionally, further studies should include other water sources in the area like rain water, river and dam. 


\section{Authors' contributions}

EBI, YUD and LM: Substantially contributed to the conception and design of study. EBI: Drafted the manuscript, analysed and interpreted the results. YUD and LM: Carried out the laboratory works, revised manuscript for important intellectual content. All authors read and approved the final manuscript.

\section{Acknowledgements}

The authors are thankful to the authorities of the Department of Theriogenology and Animal Production, Faculty of Veterinary Medicine, Usmanu Danfodiyo University Sokoto, Nigeria, for leasing out the department's poultry house and equipment to carry out this investigation. All authors contributed financially to the study.

\section{Competing interests}

The authors declare that they have no competing interests.

\section{References}

1. Jeff Behar, (2013) Tired? Aged? Not Losing Weight? Add This 1 Nutrient and See a HUGE Change. In: The Premier Muscle and Fitness, Nutrition and Health Resource Portal. MuscleMagFitness.com. Accessed on $23^{\text {rd }}$ June, 2013.

2. Yasser Saleem Mustafa, M.A. Muneer and Rahat Muneer, (2011) Influence of water restriction on the hematology of broilers. Sci. Int. (Lahore), 23(2): 127-128.

3. Abdullah, A.M. (2011) Impact of Different Locations Water Quality in Basra Province on the Performance and Physiological Changes in Broiler Chicks. Pakistan Journal of Nutrition, 10 (1): 86-94.

4. USPOULTRY (2012) Poultry Seminar Centers on Proper Vaccination, Flock Condition. In: USPOULTRY 's Poultry Production and Health Seminar in Nashville, Tenn., (Oct. 17, 2012). www.uspoultry.org. Accessed on $1^{\text {st }}$ February, 2013.

5. Abdullah, A.M. (2011) Impact of Different Locations Water Quality in Basra Province on the Performance and Physiological Changes in Broiler Chicks. Pakistan Journal of Nutrition, 10 (1): 86-94.

6. Michael Garden and Robin Singleton. (2008). Broiler Management for Birds Grown to Low Kill Weights (1.5-1.8 kg/3.3-4.0 lb). Arbor Acres Service Bulletin, Pp. 1-5.

7. Lacy, M.P. (2002) Broiler Management. In: Commercial
Chicken Meat and Egg Production (D.B. Bell and N.D. Weaver ads). $5^{\text {th }}$ ed. Springer, USA pp. 829-868.

8. Sastry, N.S.R. and Thomas, C.K. (1981) Farm Animal Management. Vikas Publishing House Pvt. Ltd., pp: 1-391.

9. Cheeke, P.R., Patton, N.M., Lukefahr, S.O. and McNitt, J.I. (1987) Rabbit production, Danville. Illion's, Pp 1.

10. Aganga, A.A. (1992) Water utilization by sheep and goats in northern Nigeria. World Anim. Rev., FAO 73, 9-14.

11. Federal Republic of Nigeria Official Gazette. (15 May 2007).

12. Anon, (2001) Sokoto State - The Seat of the Caliphate, In Sokoto State Government diary. Pp 2-8.

13. Snell, E. (1974) Encyclopaedia of industrial chemical analysis. John Weley and Sons New York, London Vol. 19. Pp 357-378.

14. Cheesbrough Monica (2002) Biochemical test to identify bacteria. In: District Laboratory in Tropical Countries. Part 2. Cambridge University Press. Pp. 63-70.

15. Fawole, M.O. and Oso, B.A. (1995) Methods of bacterial count in water. In: Manual of Microbiology. Spectrum Books Limited. Polygraphic Press Ltd. Pp. 77.

16. Asaniyan, E.K., Adene, I.C. and Adekunle, S.A. (2012) Effect of drinking water sources on performance and carcass indices of broiler chickens. Nigerian Journal of Animal Production, 39: 46-53.

17. Abbas, E.E., Alfadil, A.E. and Omar, H.A. (2008) Drinking water quality and its effect on broiler chicks. International Journal of Poultry Science, (5): 433-456.

18. Folorunsho, O.R., Laseinde, E.A.O. and Onibi, G.E. (2011) Physico-chemical composition of water from different sources for broiler production. App. Trop. Agric., 15 (1\&2): 53-59.

19. Zimmermann, N.G. and Douglass, L. (1998) A survey of drinking water quality and its effects on broiler growth performance on Delmerva. Poultry Science, 77(1): 121.

20. Folorunsho, O.R., Laseinde, E.A.O. and Onibi, G.E. (2012) Performance, haematology and carcass characteristics of broiler chickens given water from different sources. Nigerian Journal of Animal Production, 39 (1): 104-113.

21. Asaniyan, E.K. and Adene, I.C. (2013) Influence of drinking water sources on haematological indices of broiler chicken. Proc. $38^{\text {th }}$ Conf., of Nig. Soc. Anim. Prod. $17^{\text {th }}-20^{\text {th }}$ March, 2013, Rivers State University of Sci. \& Tech., Port Harcourt Nigeria. Pp. 648-650.

22. Chauhan, H.V.S. and Roy, S. (2008) Poultry diseases diagnosis and treatment. New Age International (p) Ltd. Publishers; New Delhi third ed. Pp 200-202.

23. Agriculture and Agri-Food Canada, (2010) Livestock Water Quality. www.agr.gc Accessed on $7^{\text {th }}$ March, 2013. 